\title{
Feeding preference of Euborellia annulipes to Plutella xylostella: effects of temperature and prey development stage ${ }^{1}$
}

\author{
Gilmar da Silva Nunes², Hágabo Honorato de Paulo², \\ Welliny Soares Rocha Dias², Sergio Antonio De Bortoli
}

\section{ABSTRACT}

The ring-legged earwig Euborellia annulipes has been studied as a natural enemy of pest-insects and a potential predator of diamondback moth. Temperature is an important factor that mediates the pest population density and may affect the predator-prey relationship dynamics. This study aimed to evaluate the effect of the temperature and development stage of Plutella xylostella individuals on the feeding preference of E. annulipes females. Three temperatures $\left(18{ }^{\circ} \mathrm{C}, 25{ }^{\circ} \mathrm{C}\right.$ and $32{ }^{\circ} \mathrm{C}$ ), two development stages (larvae and pupae) and two feeding conditions related to the prey capture (with or without choice) were assessed. No matter the temperature, ring-legged earwig females showed a preference for eating larvae, instead of pupae. The temperature and choice conditions influenced the amount of consumed preys, but only for larvae (not for pupae). The lowest larvae consumption was observed at $18{ }^{\circ} \mathrm{C}$, in both prey capture conditions.

KEYWORDS: Biological control, brassicas, earwig, integrated pest management, thermal conditions.

\section{INTRODUCTION}

Brassicas (Brassicaceae) are vegetables cropped worldwide that have several nutritional and bioenergetic properties (Soengas et al. 2011). Despite Brassica spp. being easy to cultivate, the damages caused by Plutella xylostella (L.) (Lepidoptera: Plutellidae), known as diamondback moth, affect the crop yield and generate high economic impacts by increasing management and control costs (Zalucki et al. 2012).

Chemical control is the most used method for the suppression of $P$. xylostella populations in plantations. However, the applied synthetic products commonly generate high toxicological risks to

\section{RESUMO}

Preferência alimentar de Euborellia annulipes por Plutella xylostella: efeitos de temperatura e estágio de desenvolvimento da presa

A tesourinha Euborellia annulipes vem sendo estudada como inimigo natural de insetos-pragas e potencial predadora da traça-dascrucíferas. A temperatura é um fator importante para mediar o aumento da densidade populacional de pragas, podendo afetar as dinâmicas da relação predador-presa. Objetivou-se avaliar o efeito da temperatura e do estágio de desenvolvimento de indivíduos de Plutella xylostella na preferência alimentar de fềmeas de $E$. annulipes. Três temperaturas $\left(18^{\circ} \mathrm{C}, 25^{\circ} \mathrm{C}\right.$ e $32^{\circ} \mathrm{C}$ ), dois estágios de desenvolvimento (lagartas e pupas) e duas condições de alimentação relacionadas à captura das presas (com e sem escolha) foram avaliados. Independentemente da temperatura, fềmeas de tesourinha mostraram preferência alimentar por lagartas, ao invés de pupas. As condições de temperatura e de escolha influenciaram na quantidade de presas consumidas, mas apenas para larvas (não para pupas). O menor consumo de lagartas foi observado sob $18^{\circ} \mathrm{C}$, em ambas as condições de captura.

PALAVRAS-CHAVE: Controle biológico, brássicas, tesourinha, manejo integrado de pragas, condições térmicas.

the environment and to human beings, besides resulting in the evolution of insect resistance after continuous applications (Tsaboula et al. 2016, Troczka et al. 2017). Thus, biological control has been increasingly emphasized as one of the possibilities for the reduction of pest infestations in agricultural crops, especially in scenarios in which the reduction or elimination of pesticides is linked to integrated pest management approaches. Formulated bioinsecticides have been used as substitutes for synthetic insecticides; however, P. xylostella larvae present a rapid resistance evolution to both types of products (Furlong et al. 2013). Therefore, the number of researches focused on natural enemies (parasitoids

1. Received: Mar. 20, 2019. Accepted: June 07, 2019. Published: Feb. 27, 2020. DOI: 10.1590/1983-40632020v5057778.

2. Universidade Estadual Paulista, Departamento de Fitossanidade, Jaboticabal, SP, Brasil.

E-mail/ORCID: gilmarsilvanunes@gmail.com/0000-0002-8310-1987, hagabohp@hotmail.com/0000-0003-0554-8027, wellinyrocha@gmail.com/0000-0002-9527-1780,bortoli@fcav.unesp.br/0000-0003-0957-6164. 
and predators) of this insect-pest has been increasing (Bai et al. 2011, Vacari et al. 2013).

Earwigs (Dermaptera) are insects with a high potential to act as natural enemies and are found in brassica crops (Kocarek et al. 2015, Ribeiro \& Gontijo 2017, Rana et al. 2019). Euborellia annulipes (Lucas) (Dermaptera: Anisolabididae) is a voracious predator of larvae and pupae of various insects, including P. xylostella (Silva et al. 2009, Moral et al. 2017, Nunes et al. 2018). Moreover, this predator can be mass reared under laboratory conditions using artificial diets (Silva et al. 2018).

Among the biotic and abiotic factors that affect arthropods, temperature is one of the most critical, influencing the population variation, growth, development, reproduction and survival (Roy et al. 2003, Golizadeh et al. 2009). In addition, temperature may also affect the dynamics between prey and natural enemies in different agricultural production systems (Murrel \& Barton 2017). The interactions between predators and preys at different temperatures are quite important in ecological studies, especially when they involve knowledge about predation behavior in different food webs, and may be applied to biological control (Petchey et al. 2010, Englund et al. 2011).

The P. xylostella species is a cosmopolitan pest distributed in tropical, cold and temperate regions (Furlong et al. 2013), easily adapting to different thermal conditions (Golizadeh et al. 2009, Marchioro \& Foerster 2011, Ngowi et al. 2017). This characteristic is shared with the E. annulipes predator, which is also a cosmopolitan insect. Detailed studies on its relationship with temperature, in a context applied to biological development, have been performed, but not on predation behavior (Lemos et al. 1998, Lemos et al. 2003).

This study aimed to evaluate the effect of the temperature and development stage of $P$. xylostella on the feeding preference of E. annulipes. The understanding of the predator action at different temperatures may aid in the decision making process, regarding the management of this important pestinsect of brassicas.

\section{MATERIAL AND METHODS}

The experiment was carried out in a laboratory of the Universidade Estadual Paulista, in Jaboticabal (São Paulo state, Brazil), in April 2018. Adult females of $E$. annulipes were used as predators and
P. xylostella larvae as preys. Both species were reared in the laboratory.

Ring-legged earwigs were reared at $25 \pm 2{ }^{\circ} \mathrm{C}$, relative humidity $(\mathrm{RH})$ of $70 \pm 10 \%$ and photoperiod of 12:12 h (light:dark) (Lemos et al. 1998). They were fed with the artificial diet described by Silva et al. (2009). Forty nymphs were placed in circular plastic cages ( $9 \mathrm{~cm}$ high $\times 15 \mathrm{~cm}$ in diameter) containing strips of moistened filter paper folded in a W-shape for refuge, and their diet was supplied in Eppendorf tubes $(2 \mathrm{~mL})$. Adults were transferred to rectangular cages $(13 \mathrm{~cm} \times 20 \mathrm{~cm} \times 7 \mathrm{~cm})$ at the density of 36 individuals per recipient, in a sexual ratio of $3: 1$ (female:male). Refuge and diet were also provided to adults, as previously described. Eggs were kept with the females to guarantee the parental care, which is common to dermapteran species (Lemos et al. 2003).

P. xylostella specimens were reared at $25 \pm$ $2{ }^{\circ} \mathrm{C}, \mathrm{RH}$ of $70 \pm 10 \%$ and photoperiod of $12: 12 \mathrm{~h}$ (light:dark). Larvae were kept in rectangular plastic containers $(13 \mathrm{~cm} \times 20 \mathrm{~cm} \times 7 \mathrm{~cm})$ with cabbage leaves (Brassica oleracea var. oleracea) as food, which were changed daily until the pupal stage was reached. Pupae were transferred to flat bottom test tubes $(8 \mathrm{~cm}$ high $\times 2 \mathrm{~cm}$ in diameter) sealed with plastic film. The obtained adults were then transferred to plastic cages ( $15 \mathrm{~cm}$ in height $\times 15 \mathrm{~cm}$ in diameter) containing leaf discs (substrate for oviposition) placed on moistened filter paper ( $8 \mathrm{~cm}$ in diameter). The obtained eggs were removed and kept in Petri dishes ( $9 \mathrm{~cm}$ in diameter) to maintain the breeding cycle.

The experiments were carried out using $E$. annulipes females because of their higher predatory activity, if compared to nymphs and males of the species (Moral et al. 2017, Nunes et al. 2018). Predators were kept without food for $24 \mathrm{~h}$, and then they were submitted to feeding preference tests in air-conditioned chambers (type B.O.D.), at three temperature conditions: $18{ }^{\circ} \mathrm{C}, 25{ }^{\circ} \mathrm{C}$ and $32{ }^{\circ} \mathrm{C}$. According to Lemos et al. (2003), the most suitable temperature for the development of E. annulipes is $25^{\circ} \mathrm{C}$. Thus, this temperature plus a lower and a higher temperature were selected for the test. Larvae and pupae were distributed in Petri dishes (16 cm in diameter) containing four leaf discs ( $4 \mathrm{~cm}$ in diameter) equidistantly distributed, leaving the center of the plate free for the release of the predator. The predator females were then stimulated to consume preys in conditions 'with choice' or 'no choice', including only larvae (in the fourth instar), only pupae or both stages (Figure 1). 


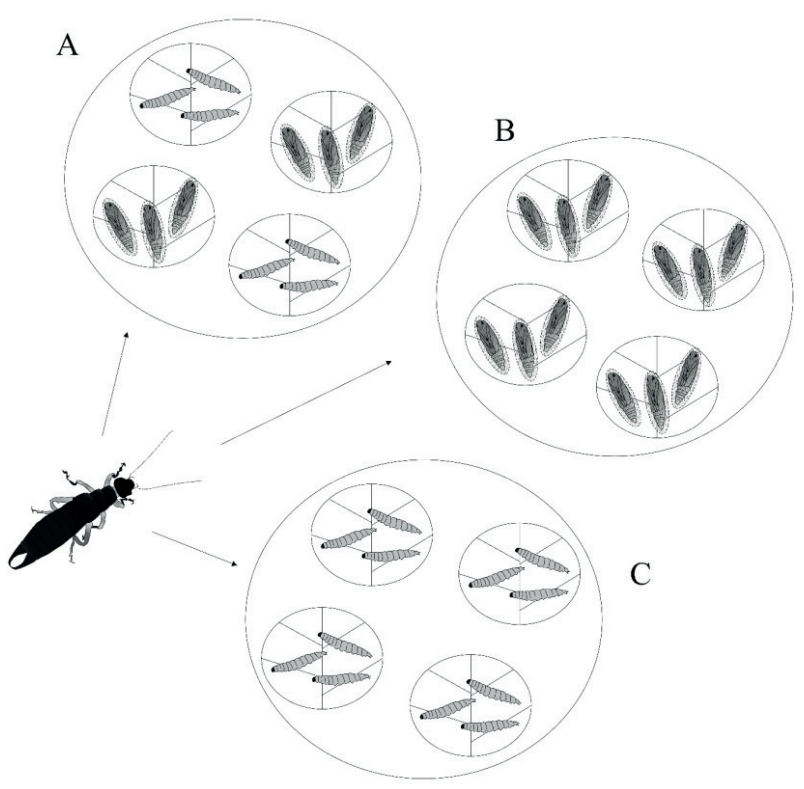

Figure 1. Scheme of the chambers used in the feeding preference test of Euborellia annulipes females to predation of Plutella xylostella under different conditions: "with choice' of larvae or pupae (A), 'no choice' with pupae (B) and 'no choice' with larvae (C).

In the chamber under the 'with choice' condition, 60 preys (30 larvae +30 pupae) were distributed on the leaf discs; whereas, in the 'no choice' condition, 60 larvae and 60 pupae were isolated. A predator (adult female) was used for each replicate. The number of provided preys was based on the E. annulipes predation rate recorded by Nunes et al. (2018). As this dermapteran species has a nocturnal habit and a predominantly nocturnal predatory activity (Lemos et al. 2003, NaranjoGuevara et al. 2017), the number of consumed preys was evaluated after $12 \mathrm{~h}$ of predator-prey exposure (06:00 p.m. to 06:00 a.m.). The obtained values were compared among the preference conditions, regarding the $P$. xylostella development stage and temperature condition.

A completely randomized design, in a $3 \times$ $2 \times 2$ (temperature $\times$ prey stage $\times$ choice condition) factorial scheme, was used, with ten replicates in each test. The obtained data were submitted to analysis of variance, and the treatment means for prey consumption were compared using the $\mathrm{F}$ and Tukey tests at $5 \%$ of probability $(\alpha=0.05)$. The mean percentages of consumed preys for the different combinations of temperature and prey stage were calculated and compared by the $\chi^{2}$ test, using the
Proc Freq of the SAS package (SAS Institute 2015). Moreover, the feeding preference regarding the "prey stage $\times$ temperature" interaction was calculated by the preference index $\beta$ of Manly (1974):

$$
\beta=\log \left(e_{1} / A_{1}\right) /\left[\log \left(e_{1} / A_{1}\right)+\log \left(e_{2} / A_{2}\right)\right]
$$

where: $e_{1}$ and $e_{2}$ are the number of preys remaining after the experimentation interval, respectively for larvae (fourth instar) and pupae (2-day-old); and $A_{1}$ and $A_{2}$ are the number of preys of each respective type (larvae or pupae). $\beta=0.5, \beta>0.5$ and $\beta<0.5$ indicate no preference and preference for larvae and pupae, respectively.

This method considers the depletion of prey density resulting from predation during the experimental evaluation (Sherratt \& Harvey 1993). Differences between each preference index and among temperatures were evaluated using the $t$-test and Tukey test at $\alpha=0.05$.

\section{RESULTS AND DISCUSSION}

The number of $P$. xylostella fourth instar larvae consumed by $E$. annulipes females was higher than that of pupae, in all tested temperatures $(\mathrm{F}=11.65$; $\mathrm{p}<0.01)$ and prey choice conditions $(\mathrm{F}=56.68$; $\mathrm{p}<0.01)$. There was also a significant "temperature $\times$ prey stage $\times$ choice" interaction $(\mathrm{F}=8.86 ; \mathrm{p}<0.01)$. Thus, considering the influence of temperature on each prey development stage, there was no effect for pupae consumption $(F=2.99 ; p=0.06)$, whereas larvae were less consumed at $18{ }^{\circ} \mathrm{C}(\mathrm{F}=43.00$; $\mathrm{p}<0.01$ ), when compared to the other temperatures (Figure 2).

The higher consumption of $P$. xylostella larvae, when compared to pupae (Figure 2), may be related to morphological factors, stiffness of the pupal integument and behavioral prey, as well as to the movement of larvae. These factors are considered defensive prey mechanisms and, when associated with other physiological and chemical factors, for example, they can reduce the rate of confrontation and influence predation (Holling 1959, Crawley 1992, Zanuncio et al. 2008). However, the prey movement stimulates predator attacks in some cases (Dixon 2000), as detected for nymphs and females of E. annulipes preying on P. xylostella (Nunes et al. 2018).

Earwigs show a high foraging capacity, exploring the soil and plants to search for food (Abramson et al. 2007, Torres \& Ruberson 2007). 

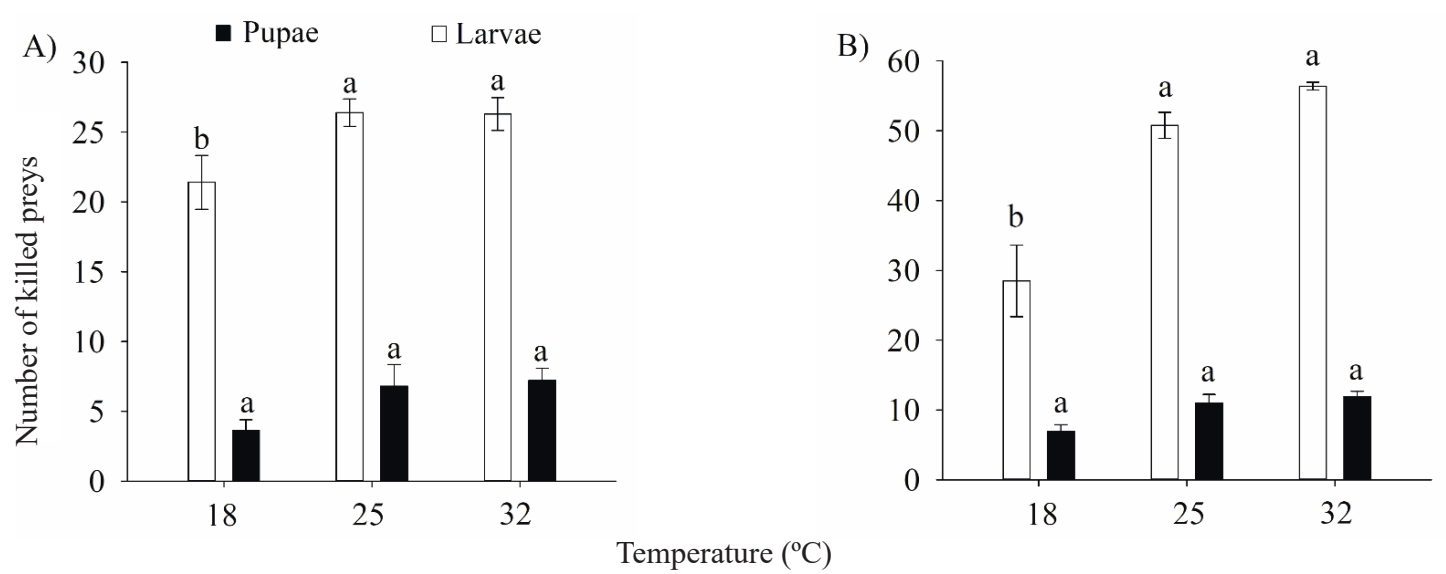

Figure 2. Mean predation rate of Plutella xylostella larvae and pupae by Euborellia annulipes at different temperatures, during a 12-h nocturnal period, under the conditions 'with choice' (A) or 'no choice' (B) to capture preys. Bars above the columns represent the standard errors of the means, which, if followed by the same letter within each development stage, do not differ by the Tukey test at $5 \%$ of probability.

Under field conditions, P. xylostella larvae may flee vigorously from an attack and hang onto plant leaves by producing a silk thread (Wang \& Keller 2002). This may lead the predator to attack other preys, such as pupae, which cannot detach from the place where they are fixed (i.e., new leaves or older ones fallen on the ground). According to Rall et al. (2010), the temperature does not influence the search and capture rate of predators, as they can be restricted by many factors such as predator detection capacity and prey mobility; however, higher temperatures may alter certain predator-prey interactions, such as the ingestion or starvation rate of the predator.

At temperatures of $25^{\circ} \mathrm{C}$ and $32^{\circ} \mathrm{C}$, an increase in the consumption of $P$. xylostella larvae was found, which may be associated with the reduction of prey moisture. The need of moisture for the dermapteran development (Lemos et al. 1998) may lead insects to seek water supplementation in larvae, whose water content is higher, when compared to that of pupae.

The development stage of $P$. xylostella influenced the consumption by E. annulipes at the different temperatures, and larvae were more consumed than pupae. Despite the differences observed between the prey stages, no influence of 'choice' conditions on the consumption of P. xylostella larvae at $18^{\circ} \mathrm{C}$ was noted $\left(\chi^{2}=0.88 ; \mathrm{p}=\right.$ 0.35 ), in which an average of $35.7 \%$ of larvae were consumed. At $18^{\circ} \mathrm{C}$, the highest pupae consumption occurred in the 'no choice' condition $\left(\chi^{2}=22.67\right.$; $\mathrm{p}<0.01)$. Larvae and pupae were most preyed in the 'no choice' condition, both at $25^{\circ} \mathrm{C}\left(\chi^{2}=79.46\right.$; $\mathrm{p}<0.01$ and $\left.\chi^{2}=110.48 ; \mathrm{p}<0.01\right)$ and $32^{\circ} \mathrm{C}\left(\chi^{2}=\right.$ 14.45; $\mathrm{p}<0.01$ and $\chi^{2}=21.94 ; \mathrm{p}<0.01$ ) (Figure 3).

The Manly's preference index estimated for the E. annulipes consumption of $P$. xylostella larvae and pupae was not influenced by temperature $(\mathrm{F}=0.11 ; \mathrm{p}=0.90)$. However, the influence of the prey development stage on each temperature was significant $(\mathrm{p}<0.01)$, and ranged $0.72-0.74$ for larvae and $0.26-0.28$ for pupae (Table 1).

The lack of influence of the temperature on the feeding preference has also been observed in other biological control agents, for which other interaction

Table 1. Manly's index (mean \pm standard error) $^{1}$ for feeding preference of Euborellia annulipes females having Plutella xylostella larvae (fourth instar) and pupae (2-day-old) as preys, during a 12-h nocturnal period, under laboratory conditions.

\begin{tabular}{ccccc}
\hline \multirow{2}{*}{ Temperature $\left({ }^{\circ} \mathrm{C}\right)$} & \multicolumn{2}{c}{ Prey development stage } & \multirow{2}{*}{ t-test } & p-value \\
\cline { 2 - 3 } & Larvae & Pupae & & 12.89 \\
25 & $0.74 \pm 0.03 \mathrm{aA}$ & $0.26 \pm 0.03 \mathrm{aB}$ & & $<0.0001$ \\
32 & $0.73 \pm 0.02 \mathrm{aA}$ & $0.27 \pm 0.02 \mathrm{aB}$ & 13.66 & $<0.0001$ \\
\hline 18 & $0.72 \pm 0.02 \mathrm{aA}$ & $0.28 \pm 0.02 \mathrm{aB}$ & 21.08 & $<0.0001$ \\
\hline
\end{tabular}

Means followed by the same lowercase letter in the row did not differ by the Tukey test $(\mathrm{p}<0.05)$. Uppercase letters indicate mean differences between the prey stages by the Student t-test. 


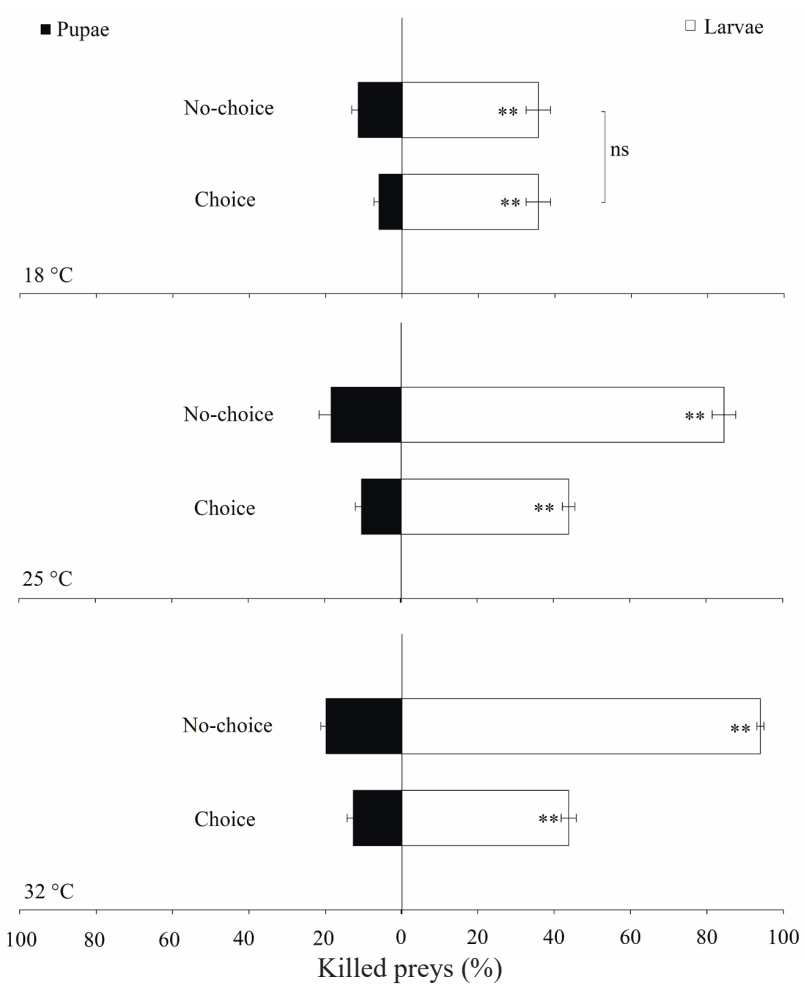

Figure 3. Percentage (mean \pm standard error) of Plutella xylostella larvae and pupae consumed by Euborellia annulipes during a 12-h nocturnal period in feeding preference tests under different temperatures and conditions to prey capture (photoperiod 12L:12D; relative humidity of $70 \pm 10 \%)$. ** Significant differences $(\mathrm{p}<0.001)$ between the prey development stages on each temperature; ns: no significant difference $(\mathrm{p}>0.05)$ between the prey choice conditions for each stage and temperature.

factors such as prey development stage (Ma et al. 2005) and pathogen infection (Jarrahi \& Safavi 2016) were more important. Predator stage, color, type and size of preys are other factors that favor a higher predation rate and feeding preference (Silva et al. 2009, Huang \& Enkengaard 2010, Farhoudi et al. 2014, Dinis et al. 2016). Feeding on smaller preys with a tender integument may lead to a decrease in the predator handling time, which is probably faster in larvae than in pupae, thereby increasing the time available for the search of other preys (Lang et al. 2012). Although, in this study, pupae are less preferred by E. annulipes than larvae, they may be more nutritious and have a different influence in other aspects, such as weight gain, fecundity and fertility of the predator. Therefore, the feeding preference herein obtained for this predator may be associated with prey detection rather than with nutritional quality (Huang \& Enkengaard 2010, Morales-Ramos et al. 2015).

The high ability of the predator to kill $P$. xylostella at increased temperatures may be related to changes in the foraging behavior and predatory activity, which have high energy costs, or to thermal preferences that will influence their fertility (Lemos et al. 2003, Dib et al. 2011).

Factors such as prey population density and intraguild predation may also interfere in the food preference and other predator behaviors, such as functional response (Holling 1959, Dib et al. 2011, Yu et al. 2019), suggesting the need of further studies. The phenology and temperature-dependent behavior of some earwig species have already been reported (Helsen et al. 1998, Lordan et al. 2014), but few studies have described these factors for E. annulipes. The results obtained here indicate that the ring-legged earwig may have an important contribution to the pest control in regions of mild or hot climates, where increases in pest density may occur. Considering the limited number of studies focused on the efficiency of P. xylostella's natural enemies, including predators, and the increase of surveys on earwigs, this study is also important to endorse management strategies.

\section{CONCLUSIONS}

1. The ring-legged earwig Euborellia annulipes shows a feeding preference for Plutella xylostella larvae (fourth instar), instead of pupae (2-day-old);

2. Temperature $\left(18{ }^{\circ} \mathrm{C}\right.$ to $\left.32^{\circ} \mathrm{C}\right)$ and prey choice conditions influence the amount of consumed preys by E. annulipes, but only for P. xylostella larvae (not for pupae); and the lowest consumption occurs at $18^{\circ} \mathrm{C}$.

\section{ACKNOWLEDGMENTS}

We would like to thank the Coordenação de Aperfeiçoamento de Pessoal de Nível Superior (Capes, MEC - Brazil - Finance Code 001) for financially supporting this research.

\section{REFERENCES}

ABRAMSON, C. I.; WNADERLEY, P. A.; MINÁ, A. J. S.; WANDERLEY, M. J. A. Capacity of earwig Marava arachidis (Yersin) to access fennel plants Foeniculum 
vulgare Mill in laboratory and field. Ciência Rural, v. 37, n. 6, p. 1524-1528, 2007.

BAI, S. F.; LI, X.; CHEN, X. X.; HE, J. H. Interspecific competition between two endoparasitoids Cotesia vestalis (Hymenoptera:Braconidae) and Oomyzus sokolowskii (Hymenoptera:Eulophidae). Archives of Insect Biochemistry and Physiology, v. 76, n. 3, p. 156167, 2011.

CRAWLEY, M. J. Natural enemies: the population biology of predators, parasites and diseases. Oxford: Blackwell Scientific Publications, 1992.

DIB, H.; JAMONT, M.; SAUPHANOR, B.; CAPOWIEZ, $Y$. Predation potency and intraguild interactions between generalist (Forficula auricularia) and specialist (Episyrphus balteatus) predators of the rosy apple aphid (Dysaphis plantaginea). Biological Control, v. 59, n. 2, p. 90-97, 2011.

DINIS, A. M.; PEREIRA, J. A.; BENHADI-MARIN, J.; SANTOS, S. A. Feeding preferences and functional responses of Calathus granatensis and Pterostichus globosus (Coleoptera:Carabidae) on pupae of Bactrocera oleae (Diptera:Tephritidae). Bulletin of Entomological Research, v. 106, n. 6, p. 701-709, 2016.

DIXON, A. F. G. Insect predator prey dynamics, lady bird beetles and biological control. Cambridge: Cambridge University Press, 2000.

ENGLUND, G.; ÖHLUND, G.; HEIN, C. L.; DIEHL, $\mathrm{S}$. Temperature dependence of the functional response. Ecology Letters, v. 14, n. 9, p. 914-921, 2011.

FARHOUDI, F.; ALLAHYARI, H.; TABADKANI, S. M.; GHOLIZADEH, M. Prey preference of Aphidoletes aphidimyza on Acyrthosiphon pisum: effect of prey color and size. Journal of Insect Behavior, v. 27, n. 6, p. 776785, 2014.

FURLONG, M. J.; WRIGHT, D. J.; DOSDALL, L. M. Diamondback moth ecology and management: problems, progress, and prospects. Annual Review of Entomology, v. 58, n. 1, p. 517-541, 2013.

GOLIZADEH, A.; KAMALI, K.; FATHIPOUR, Y.; ABBASIPOUR, H. Effect of temperature on life table parameters of Plutella xylostella (Lepidoptera: Plutellidae) on two brassicaceous host plants. Journal of Asia-Pacific Entomology, v. 12, n. 4, p. 207-212, 2009.

HELSEN, H.; VAAL, F.; BLOMMERS, L. Phenology of the common earwig Forficula auricularia L. (Dermaptera: Forficulidae) in an apple orchard. International Journal of Pest Management, v. 44, n. 2, p. 75-79, 1998.

HOLLING, C. S. Some characteristics of simple types of predation and parasitism. Canadian Entomologist, v. 91, n. 7, p. 385-398, 1959.

HUANG, N.; ENKEGAARD, A. Predation capacity and prey preference of Chrysoperla carnea on Pieris brassicae. BioControl, v. 55, n. 3, p. 379-385, 2010.
JARRAHI, A.; SAFAVI, S. A. Temperature-dependent functional response and host preference of Habrobracon hebetor between fungus-infected and uninfected Ephestia kuehniella larvae. Journal of Stored Products Research, v. 67, n. 1, p. 41-48, 2016.

KOCAREK, P.; DVORAK, L.; KIRSTOVA, M. Euborellia annulipes (Dermaptera:Anisolabididae), a new alien earwig in Central European greenhouses: potential pest or beneficial inhabitant? Applied Entomology and Zoology, v. 50, n. 2, p. 201-206, 2015.

LANG, B.; RALL, B. C.; BROSE, U. Warming effects on consumption and intraspecific interference competition depend on predator metabolism. Journal of Animal Ecology, v. 81, n. 3, p. 516-523, 2012.

LEMOS, W. P.; MEDEIROS, R. S.; RAMALHO, F. S. Influência da temperatura no desenvolvimento de Euborellia annulipes (Lucas) (Dermaptera:Anisolabididae), predador do bicudo-do-algodoeiro. Anais da Sociedade Entomológica do Brasil, v. 27, n. 1, p. 67-76, 1998.

LEMOS, W. P.; RAMALHO, F. S.; ZANUNCIO, J. C. Agedependent fecundity and life-fertility tables for Euborellia annulipes (Lucas) (Dermaptera:Anisolabididae) a cotton boll weevil predator in laboratory studies with an artificial diet. Environmental Entomology, v. 32, n. 3, p. 592-601, 2003.

LORDAN, J.; ALEGRE, S.; BLANCO, R.; SARASÚA, M. J.; ALINS, G. Aggregation behavior in the European earwig: response to impregnated shelters. Crop Protection, v. 65, n. 1, p. 71-76, 2014.

MA, J.; LI, Y. Z.; KELLER, M.; REN, S. X. Functional response and predation of Nabis kinbergii (Hemiptera: Nabidae) to Plutella xylostella (Lepidoptera:Plutellidae). Insect Science, v. 12, n. 4, p. 281-286, 2005.

MANLY, B. F. J. A model for certain types of selection experiments. Biometrics, v. 30, n. 2, p. 281-294, 1974.

MARCHIORO, C. A.; FOERSTER, L. A. Development and survival of the diamondback moth, Plutella xylostella (L.) (Lepidoptera:Yponomeutidae) as a function of temperature: effect on the number of generations in tropical and subtropical regions. Neotropical Entomology, v. 40, n. 5, p. 533-541, 2011.

MORAL, R. A.; DEMÉTRIO, C. G. B.; HINDE, J.; GODOY, W. A. C.; FERNANDES, F. S. Parasitismmediated prey selectivity in laboratory conditions and implications for biological control. Basic and Applied Ecology, v. 19, n. 1, p. 67-75, 2017.

MORALES-RAMOS, J. A.; ROJAS, M. G.; SHELBY, K. S.; COUDRON, T. A. Nutritional value of pupae versus larvae of Tenebrio molitor (Coleoptera:Tenebrionidae) as food for rearing Podisus maculiventris (Heteroptera: Pentatomidae). Journal of Economic Entomology, v. 109, n. 2, p. 564-571, 2015.

MURRELL, E. G.; BARTON, B. T. Warming alters prey density and biological control in conventional and 
organic agricultural systems. Integrative and Comparative Biology, v. 57, n. 1, p. 1-13, 2017.

NARANJO-GUEVARA, N.; PEÑAFLOR, M. F. G.; CABEZAS-GUERRERO, M. F.; BENTO, J. M. S. Nocturnal herbivore-induced plant volatiles attract the generalist predatory earwig Doru luteipes Scudder. The Science of Nature, v. 104, n. 9-10, e77, 2017.

NGOWI, B. V.; TONNANG, H. E.; MWANGI, E. M.; JOHANSSON, T.; AMBALE, J.; NDEGWA, P. N.; SUBRAMANIAN, S. Temperature-dependent phenology of Plutella xylostella (Lepidoptera:Plutellidae): simulation and visualization of current and future distributions along the Eastern Afromontane. PloS One, v. 12, n. 3, e0173590, 2017.

NUNES, G. S.; DANTAS, T. A. V.; FIGUEIREDO, W. R. S.; SOUZA, M. S. S.; NASCIMENTO, I. N. do; BATISTA, J. L. Predation of diamondback moth larvae and pupae by Euborellia annulipes. Revista Brasileira de Ciências Agrárias (Agrária), v. 13, n. 3, p. 1-8, 2018.

PETCHEY, O. L.; BROSE, U.; RALL, B. C. Predicting the effects of temperature on food web connectance. Philosophical Transactions of the Royal Society of London B: Biological Sciences, v. 365, n. 1549, p. 2081-2091, 2010.

RALL, B. C.; VUCIC-PESTIC, O.; EHNES, R. B.; EMMERSON, M.; BROSE, U. Temperature, predatorprey interaction strength and population stability. Global Change Biology, v. 16, n. 8, p. 2145-2157, 2010.

RANA, N.; AZAM, S.; RIASAT, S.; RUQIA, G.; RASHEED, F.; KANWAL, S.; NARGIS, S.; SHABIR, A.; ALI, M.; IQBAL, M. Z. Prevallence of macro-invertebrate among cauliflower (Brassica oleracea var. capitata) and tomato (Solanum lycopersicum L.). Blanco cv. Feutrell's Early. International Journal of Advances in Agriculture Sciences, v. 4, n. 1, p. 1-9, 2019.

RIBEIRO, A. L.; GONTIJO, L. M. Alyssum flowers promote biological control of collard pests. BioControl, v. 62 , n. 2, p. 185-196, 2017.

ROY, M.; BRODEUR, J.; CLOUTIER, C. Effect of temperature on intrinsic rates of natural increase $\left(r_{\mathrm{m}}\right)$ of a coccinellid and its spider mite prey. BioControl, v. 48, n. 1, p. 57-72, 2003.

SAS INSTITUTE. SAS/IML ${ }^{\circledR}$ user's guide. Cary: SAS Institute Inc., 2015.

SHERRATT, T.; HARVEY, I. F. Frequency-dependent food selection by arthropods: a review. Biological Journal of the Linnean Society, v. 48, n. 2, p. 167-186, 1993.

SILVA, A. B.; BATISTA, J. L.; BRITO, C. H. Capacidade predatória de Euborellia annulipes (Lucas, 1847) sobre Spodoptera frugiperda (Smith, 1797). Acta Scientiarum: Agronomy, v. 31, n. 1, p. 7-11, 2009.

SILVA, I. T. F. A.; OLIVEIRA, R.; OLIVEIRA, L. V. Q.; NASCIMENTO JÚNIOR, J. L.; BATISTA, J. L.
Biological development of Euborellia annulipes reared with artificial diets and Ephestia kuehniella eggs. Pesquisa Agropecuária Tropical, v. 48, n. 3, p. 295-298, 2018.

SOENGAS, M. P. F.; PÉREZ, T. S.; PAZOS, P. V.; GONZÁLEZ, M. E. C. Antioxidant properties of Brassica vegetables. Functional Plant Science and Biotechnology, v. 5, n. 2, p. 43-55, 2011.

TORRES, J. B.; RUBERSON, J. R. Abundance and diversity of ground-dwelling arthropods of pest management importance in commercial $\mathrm{Bt}$ and non- $\mathrm{Bt}$ cotton fields. Annals of Applied Biology, v. 150, n. 1, p. 27-39, 2007.

TROCZKA, B. J.; WILLIAMSON, M. S.; FIELD, L. M.; DAVIES, T. E. Rapid selection for resistance to diamide insecticides in Plutella xylostella via specific amino acid polymorphisms in the ryanodine receptor. Neurotoxicology, v. 60, n. 1, p. 224-233, 2017.

TSABOULA, A.; PAPADAKIS, E. N.; VRYZAS, Z.; KOTOPOULOU, A.; KINTZIKOGLOU, K.; PAPADOPOULOU-MOURKIDOU, E. Environmental and human risk hierarchy of pesticides: a prioritization method, based on monitoring, hazard assessment and environmental fate. Environment International, v. 91, n. 1, p. 78-93, 2016.

VACARI, A. M.; DE BORTOLI, S. A.; GOULART, R. M.; VOLPE, H. X.; OTUKA, A. K.; VEIGA, A. C. Comparison of eggs, larvae, and pupae of Plutella xylostella (Lepidoptera:Plutellidae) as prey for Podisus nigrispinus (Hemiptera:Pentatomidae). Annals of the Entomological Society of America, v. 106, n. 2, p. 235242, 2013.

WANG, X. G.; KELLER, M. A. A comparison of the host-searching efficiency of two larval parasitoids of Plutella xylostella. Ecological Entomology, v. 27, n. 1, p. 105-114, 2002.

YU, X. L.; FENG, Y.; FU, W. Y.; SUN, Y. X.; LIU, T. $\mathrm{X}$. Intraguild predation between Harmonia axyridis and Aphidius gifuensis: effects of starvation period, plant dimension and extraguild prey density. BioControl, v. 64, n. 1, p. 55-64, 2019.

ZALUCKI, M. P.; SHABBIR, A.; SILVA, R.; ADAMSON, D.; SHU-SHENG, L.; FURLONG, M. J. Estimating the economic cost of one of the world's major insect pests, Plutella xylostella (Lepidoptera: Plutellidae): just how long is a piece of string? Journal of Economic Entomology, v. 105, n. 4, p. 1115-1129, 2012.

ZANUNCIO, J. C.; SILVA, C. A. D.; LIMA, E. R.; PEREIRA, F. F.; RAMALHO, F. de S.; SERRÃO, J. E. Predation rate of Spodoptera frugiperda (Lepidoptera:Noctuidae) larvae with and without defense by Podisus nigrispinus (Heteroptera:Pentatomidae). Brazilian Archives of Biology and Technology, v. 51, n. 1, p. 121-125, 2008. 